\title{
Karma and Rebirth of Early and Theravada Buddhism
}

\author{
초기불교와 테라와다 불교의 업과 윤회 \\ Jae Sung Kim ${ }^{1}$ \\ 김재성 1 \\ ${ }^{1}$ Assistant Professor, Department of Meditational Psychology, Nungin University, Republic of Korea, \\ metta4u@niu.ac.kr
}

\begin{abstract}
This paper examines on Karma and rebirth of the Early Buddhism and Theravada Buddhism, focusing on early Buddhist scriptures and commentary literature and Abhidhamma. Karma, defined as intention, was the core idea of early Buddhism and was also the core teaching of the Buddha. It can be said that the basic position of early Buddhism was to argue for the statement of a noself rebirth that does not recognize a fixed substance, though it is reborn by karma. The commentary literature such as Visuddhimagga(The Path of Purification) analyze karma more precisely as the basis for explaining rebirth. In early Buddhism and Theravada Buddhism, the path of kamma pursuing happiness in the present and in the future by accumulating good karma such as generosity and moral precept, and the way to get Nirvana emancipating from rebirth by pursuing the 37 factors of enlightenment are not two heterogeneous paths, but the same path. It can be said that it inherits the consistent teachings of the Buddha presented in various ways. Modern Theravada Buddhism's practice of faith and meditation can be said to be a path toward the happiness of Nirvana, while pursuing various happiness.
\end{abstract}

Keywords: Early Buddhism, Theravada Buddhism, Karma, Kamma, Rebirth, No-self

요약: 본고는 초기불교와 테라와다 불교에서 말하는 업과 윤회가 무엇인지 밝히기 위해서 초 기경전과 청정도론 등의 주석문헌과 아비담마를 중심으로 한 연구이다. 의도라고 정의된 업 (karma, kamma)은 초기불교의 근본적인 입장이자 고따마 붓다의 핵심 가르침이다. 우리들은 업 을 짓기 때문에 윤회하지만 운회하는 영혼이나 자아를 상정하지 않는 무아인 오온이 윤회한 다는 사상을 강조한다. 테라와다 불교의 청정도론과 같은 주석문헌을 포함하고, 후대의 아비 담마 문헌에서는 초기불교의 업사상을 더욱 자세히 분석해서 설명하며 무아 윤회를 설명하고 있다. 초기불교 및 테라와다 불교에서는 다양한 공덕행으로 보시와 지계, 천상에 이르는 선업 (사무량심 등)을 실천해서 현생과 다음 생의 행복을 구하는 선업을 닦는 길과 초기불교 이래 불교 수행을 집대성한 37보리분법을 실천해서 괴로움의 완전한 소멸의 경지인 열반을 얻어 생사 윤회의 고통에서 벗어나는 2가지 길이 서로 이질적이 아니라, 결국은 같은 방향으로 가 는 길을 다양하게 제시한 붓다의 일관된 가르침이라고 할 수 있다. 스리랑카, 태국, 미얀마 등 의 현대 테라와다 불교를 전승하고 있는 나라들의 불교신앙, 공덕행, 그리고 명상은 이러한 다 양한 행복을 추구하는 방법이며, 이 모든 실천은 궁극적으로 불교 최상의 목적인 열반을 향한 다양한 길이다.

Received: March 31, 2021; 1st Review Result: May 15, 2021; 2nd Review Result: June 30, 2021 Accepted: July 31, 2021 
핵심어: 초기불교, 테라와다 불교, 업, 윤회, 무아

\section{1. 서론}

초기 불교 이전에 이미 업사상과 윤회사상이 인도에 존재했고, 사문사상을 대표하는 불교 및 자이나교 등에서는 서로 다른 입장에서 업사상과 윤회사상을 펼쳤다[1]. 이 논문 은 초기경전에 기반하여 남방의 테라와다 불교의 업사상과 윤회사상을 고찰해 볼 것이 다. 빠알리 삼장과 한역 아함경류 그리고 부파에서 전승하고 있는 율장으로 구성된 초기 불교 문헌에 의하면, 업과 인과응보 그리고 오온(五蘊)의 상속에 기반한 무아(無我) 윤회 사상[2]을 초기불교에 보이는 입장으로 볼 수 있다. 본고에서는 초기불교 문헌으로 파악 할 수 있는 업과 윤회에 대해 고찰한 후에 테라와다 불교 전승의 주석서와 이후의 아비 담마 문헌의 업사상과 윤회사상에 대하여 살펴보고자 한다.

\section{2. 본론}

\section{1 초기불전에 나타난 업과 윤회}

\subsection{1 의도로서의 업과 언어와 신체의 행위}

불교에서 말하는 업(業, pāli: kamma, skt: karma,)에 대한 다양한 해설을 몇 종류의 범주로 살펴보려고 한다. 먼저 빠알리 니까야 등의 초기경전에서는 “업이란 의도(cetanā)"라고 한다.

수행승들이여, 나는 의도[思,cetanā]가 업[業,kamma]이라고 말한다. 사람들은 의도한 후, 몸으로, 말로, 마음으로 업을 행한다. 수행승들이여, 지옥에서 (그 과보를) 받을 업,, 축생계에서 받을 업, 아귀계에서 받을 업, 인간계에서 받을 업, 천상계에서 받을 업이 있다. ... 수행승들이여, 나는 업의 과보에는 세 가지가 있다고 말한다. 첫째, 지금 이 생에서 그 과보를 받는 것, 둘째, 죽은 후 바로 다음 생에서 그 과보를 받는 것, 셋째, (세 번째 생 이후의)미래 생에서 그 과보를 받는 것 세 가지이다[3].

이 경전은 의도한 다음에(cetayitvā) 몸으로, 말로, 마음으로 업을 행한다(kammamkaroti) 또는 행위 한다고 한다. 그 의미는 의도가 일어난 다음에 몸으로, 말로, 마음으로 행위한다는 의미이다. ‘의도'라고 업을 정의하면, 우리의 마음으로도 알 수 있을 것이다. 또한 의도한 다음의 신구의(身口意)의 3가지 행위[三業]도 알 수 있다.

초기 경전인 『숫타니파타』에는, 태생이 아니라 업[행위]에 의하여 비천한 사람도 되고, 업에 의하여 (고귀한) 바라문도 된다고 말한다[4]. 더 나아가 인간들은 태생에 기인한 여러 특징들을 가지고 있지 않고, 인간들에게 보이는 구별은 단지 편의 상 부르는 명칭의 차이 뿐이며, 사람들의 자신이 하는 행위에 의해서 농부나, 기술자나, 상인이거나, 고용인이거나, 도둑이나, 전사나, 제관 혹은 왕으로 구별해서 불리울 뿐이라고 하며 고따마 붓다는 태생이나 가문에 의해 사람을 바라문이라고 부르지 않음을 밝히고있다[5].

\subsection{2 업의 상속과 윤회}

인간을 포함한 윤회하는 존재는 자신의 의도에 의한 업을 짓게 되면 그 과보를 받게 된다. 생명있는 모든 존재[衆生]는각자 자신의 업의 상속자이며, 업에 의해 속박된 존재이다. 『숫타니파타』에 아래와 같은 구절이 있다. 
세상은 업에 의존해서 존재하고, 인간도 업에 의존해서 존재한다. 생명있는 존재들은 모두 업에 묶여 있다. 달리는 마차가 차축에 연결되어 있듯이[6].

수행승들이여, 모든 생명 있는 존재들은 (자기가 지은) 업[業]을 자기 것으로 하며, (자기가 지은) 업의 상속자이고, 업을 모태로 하여 태어나며, 업을 친척으로 하고, 업을 의지할 곳으로 한다. 유익한 업이거나 해로운 업이거나 그 어떤 업을 짓더라도 그들은 자신의 업의 상속자가 된다[7].

업을 지은 존재가 어디에서 태어나든지 그곳에서 과거의 업은 결실을 맺으며, 업의 과보를 겪는다. 하지만 업의 과보를 경험하는 때는 확정되어 있지 않다. 모든 생명은 자신이 행한 업 때문에 윤회한다. 이 업은 근본 번뇌인 탐진치에서 생겨난다.

수행승들이여, 욕망[貪]에서 비롯되고, 욕망에서 생겨났으며, 욕망을 원인으로 하고, 욕망을 조건으로 하는 업이 존재한다. 이런 업을 지은 사람들이 태어나는 장소, 그 곳이 그러한 업의 과보가 무르익는 곳이다. 욕망에서 비롯된 업이 무르익을 때, 현생(現生)이거나, 바로 다음 생이거나, 먼 후생이거나, 존재들은 자신이 지은 업의 과보를 받는다. 분노[愼]에서 비롯되고, 분노에서 생겨났으며, 분노를 원인으로 하고, 분노를 조건으로 하는 업이 존재한다. 이러한 업을 지은 사람들이 태어나는 장소, 그 곳이 그러한 업의 과보가 무르익는 곳이다. 분노에서 비롯된 업이 무르익을 때, 현생(現生)이거나, 바로 다음 생이거나, 먼 후생이거나, 존재들은자신이 지은 업의 과보를 받는다. 무지[痴]에서 비롯되고, 무지에서 생겨났으며, 무지를 원인으로 하고, 무지를 조건으로 하는 업이 존재한다. 이러한 업을 지은 사람들이 태어나는 장소, 그 곳이 그러한 업의 과보가 무르익는 곳이다. 무지에서 비롯된 업이 무르익을 때, 현생(現生)이거나, 바로 다음 생이거나, 먼 후생이거나, 존재들은 자신이 지은 업의 과보를 받는다[8].

원인과 조건이 없는데 존재할 수 있는 것은 세상에 그 무엇도 없다는 것이 초기불교의 연기설(緣起說)인데, 이 연기설은 타고나면서부터 불공평하게 보이는 것들의 조건에 대하여 설명한다[9]. 그리고 존재들의 잠재적인 성향만이 아니라, 삶의 전체 운명, 행복과 불행 전체가 부분적으로는 현생에서 다른 부분은 과거 생에서 기인한 조건으로부터 생겨났음을 말하고 있다. 이러한 조건은 몸, 입, 마음으로 짓는 세 가지 행위[業]이다. 옥망과 분노와 무지와 결합되어 있는 해로운 행위이거나, 이 세가지와 결합되어 있지 않은 유익한 행위[業]가 기본이 되어 존재의 성향을 결정한다. 따라서 업을 정확하게 정의하면, 생사 윤회와 관련되어 있는, 유익하고 해로운 의도이다. 그리도 업에 대하여 잊어서는 안 되는 사실은 무아(無我)이다. 생사윤회에서 헤매는 존재에게는 변치 않는 자아가 아니라, 그 존재가 행하는 유익하고 해로운 행위에 따라, 현생에서는 인간으로, 다음 생에서는 짐승으로, 또 다른 생에서는 보이지 않는 존재(지옥이나 천상의 존재)로 나타나는, 생명의 파도의 한 모습일 뿐이다. '업'이라는 용어는 앞에서 언급했던 몸, 입, 마음의 3 가지 행위만을 의미하지, 그 결과를 포함하고 있지는 않다[10]. 즉 업은 본래 의도에 바탕을 둔 행위를 의미한다.

업은 생명 있는 존재들의 윤회하는 3 가지 세계인 욕망세계[欲界], (섬세한) 물질 세계[色界], 물질 없는 (정신) 세계[無色界]에서 다시 태어나는 근거가 된다. 욕계, 색계, 
무색계라는 윤회의 세계에서의 과보를 초래하는 업이 있기에 삼계(三界)의 존재가 드러나는 것이다. 윤회할 때, 업은 토양이며, 식(識)은 씨, 갈애(渴愛)는 씨앗을 싹트게 하는 물의 역할을 하며 삼계라는 존재의 세계에서 윤회한다.

세존이시여, 존재, 존재라고 사람들은 말합니다. 세존이시여, 어떻게 존재가 있게 되는 것입니까?

아난다여, 욕계(欲界)의 과보를 초래하는 업이 없다면 욕계의 존재를 주장할 수 있겠는가?

아닙니다. 세존이시여.

아난다여, 이처럼 업은 토양이고, 식(識)은 씨이며, 갈애는 물이다. 중생들은 무지에 덮여, 갈애에 속박되어 저열한 [욕망의] 세계에 식(識)을 확립한다. 이와 같이 다음 생에 다시 태어나게 된다. 아난다여, 이것이 존재다[11].

이와 같이 업은 윤회와 연결되어 있고, 자신이 과거에 지은 업에 따라 그 업에 해당하는 존재 세계에서 태어나는 것임을 초기경전에서 확인할 수 있다.

\subsection{3 업과 윤회에 대한 앎}

앞서 살펴보았듯이 초기불교는 분명하게 업과 윤회, 즉 업에 기인한 윤회를 말한다. 하지만 업에 기인한 윤회를 누구나 직접 알지 못한다. 과거생을 아는 숙명통이나 죽은 후에 태어날 곳을 아는 천안통과 같은 신통지혜를 얻을 때, 직접 알 수 있다[12]. 업과 윤회를 스스로 검증할 지혜가 없거나 그 지혜를 갖추지 못한 사람들은 믿음에 의해서 업과 윤회를 받아들여야 한다[13]. 세간의 팔정도와 출세간의 팔정도로 구분해서 설명하고 있는 초기경전을 보면 세간의 팔정도 가운데 첫번째의 바른 견해[正見]에 대해서 다음과 같이 설명한다.

수행승들이여, 번뇌가 있어(sāsavā), 어느 정도의 공덕이 있지만, 집착의 결과가 있는 바른 견해는 무엇인가? 베품[布施]은 있다. 제사도 있다. 공양의 베품도 있다. 유익한 행위와 해로운 행위 둘 다 그에 상응하는 과보가 있다. 현생도 있고 다음 생도 있다. 어머니도 있고, 아버지도 있다. (부모없이) 즉시 태어나는[化生] 중생도 있다. 이 세상에는, 바르게 유행하고 올바로 실천하는 수행자와 성직자가 있어, 이 세상과 저 세상을 스스로 알고 깨달아 설명할 수 있다는 [견해를] 번뇌가 남아있어, 어느 정도의 공덕이 있지만, 집착의 결과가 있는 [세간의] 바른 견해라고 한다[14].

위 경전은 업에는 윤리적인 인과법칙인 인과응보가 있고, 이에 의해 이 세상은 물론 죽은 후의 저 세상도 있음을 말하고 있으며, 이렇게 윤회가 실재로 있다는 사실을 자신의 지혜로 직접 알아서 말할 수 있는 자가 있음을 (믿음으로) 받아들이는 것이 이 세상에서의 정견(正見)인 바른 견해라고 하고 있다. 업에 대한 과보와 윤회는 지혜 있는 수행자가 직접 알 수 있다.

또 다른 경전에서는 "업의 과보는 생각할 수 없는 것이니 그것을 생각해서는 안 된다. 생각하면 미치거나 곤혹스럽게 된다.”[15]고 하였다. 이는 4가지 불가사의[cattāriacinteyāni: 붓다의 경지(buddhavisaya), 선禪의 경지(jhānavisaya), 업의 과보(kammavipaka), 세상에 대한 사색(lokacinta)]의 하나로, 붓다와 삼명(三明), 육신통(六神通)을 깨달은 아라한만이 업의 
과보를 파악할 수 있다고 한다[16].

\subsection{4 업론과 작용론}

불교 이외의 사상에 몸담고 있던 외도 수행자 가운데 인과나 윤회를 부정하는 자가 불교 승단에 들어와 수행승이 되려면, 4 개월 정도 정해진 곳에서 다른 승가 구성원과 떨어져 머물면서(別住), 불교 승단의 구성원인 비구들의 관찰을 받아야 한다. 승단에 들어와 4 개월이 지난 후, 몇 가지 중요한 점을 확인한 후에 승단의 구성원의 일원으로 받아들일 것인지 결정한다. 그 중에는 붓다의 가르침과 승단에 대한 찬탄을 듣고, 기뻐하는 내용이 있다. 하지만 4개월간의 별주를 면제받는 외도들이 있었는데, 그들은 업론자(kamma-vādīn)이며 작용론자(kiriya-vādīn)였던, 불을 섬기는 자들과 결발의 수행자들이었다[17]. 불교 이외의 수행자들은 업론과 작용론을 받아들이는 것이 불교 승단에의 입단을 허락하는 기준이 될 정도로 업에 대한 입장은 중요했다.

초기경전인 빠알리 니까야와 다양한 부파 전승의 한역 아함경에 의하면, 붓다는 자신을 업을 주장하는 자[업론자, kamma-vādīn]이며 행위를 주장하는 자[행위론자, kiriya-vādīn]라고 한다.

수행승들이여, 지금의 정등각자인 나도 업론자이고, 행위론자이며, 정진론자이다. 수행승들이여, 쓸모없는 인간 막칼리는 나에게 그의 교설로서 다음과 같이 반박한다. 업이란 것도 없고, 행위도 없으며, 정진이란 것도 없다고[18].

실로 사문 고타마는 업론자이고, 행위론자이며, 바라문 사람들 사이에서 존경받고 있다[19].

붓다가 업론과 행위론을 주장하는 것은 몸과 말과 마음의 악한 행위와 해로운 법을 행하거나 유익한 법을 행해도 아무런 과보가 없다는 무행위론(akiriya-vāda)에 대한 비판이며, 선악의 업에 대하여 그 결과와 과보 등을 부정하는 뿌라나까삿빠의 도덕부정설, 막칼리 고살라의 결정론에 대한 비판이기도 하다.

붓다는 업론과 행위론의 입장에서 우연론[無因論], 숙명론도 비판하고 있다. 숙명론[宿作因, pubbekata-hetu]이란 현생의 모든 고(苦), 락(樂), 불고불락 (不苦不樂)의 느낌은 과거생의 원인에 기인한다는 주장이다[20]. 이러한 견해는 자이나교의 입장임을 데바다하 경[21]에서 자세히 비판하고 있다.

업이라는 의지작용에 의거해 인간은 자신의 운명을 스스로 만들어 나가며, 자신의 행위에 의해 현재와 미래의 삶이 정해진다. 하지만 불교의 업사상을 숙명론으로 오해해서는 안 된다. 과거의 업은 이미 지었기 때문에 어찌할 수 없지만, 현재의 업은 항상 새롭게 만들 수 있으며, 업도 변하는 것이므로 각자의 노력에 의해 더 나아지게 할 수 있다는 것이 불교의 업에 대한 입장이다[22]. 초기불교의 업사상은 연기(緣起) 사상과 관련이 있음을 다음 경전을 통해 알 수 있다. '현명한 자들은 업을 있는 그대로 보고, 연기(緣起)를 보며, 업과 과보를 잘 알고 있다’[23]. 업과 그 과보를 아는 것은 연기를 아는 것이라고 볼 수 있다.

\section{2 주석문헌과 후대 아비담마의 업과 윤회}

\subsection{1『청정도론』에 보이는 업과 윤회}


붓다고사가 지은 『청정도론』에서는 옛 스승의 게송을 인용하여, 존재들의 윤회를 창조한 신은 없고, 다양한 조건에 의존된 법들이 전개된다는 점을 밝히고 있다.

어떠한 천신도 범천도 이 생사의 윤회를 만든 자는 아니다. 원인과 조건에 의존된 순수한 법들이 펼쳐지는 것이다[24].

5온과 12 처와 18 계의 연속과 끊임없는 전개를 윤회라고 한다[25].

『청정도론』에서는 이처럼 창조주를 주장하는 유신론을 부정하고, 연기론 즉 원인과 조건에 의한 발생에 근거해서, 오온, 십이처, 십팔계의 연속과 전개만이 있어 윤회할 뿐이지 어떤 중생이 있어 윤회하는 것은 아니라고 한다.

청정도론을 위시로 한 테라와다 불교의 주석문헌에 보이는 보시(布施), 지계(持戒), 수행(修行)의 실천에 의한 행복에는 3 가지가 있다. 첫째, 현재의 인간의 삶에서 경험하는 행복(manussa-sukha), 둘째, 다음 생의 천상의 행복(dibba-sukha), 셋째, 궁극적인 목적인 열반의 행복(nibbāna-sukha)이다[26]. 이 중에서 보시와 지계는 현생과 내생의 행복의 수단이며, 37보리분법을 닦는 수행은 열반의 행복을 얻기 위한 수단이다[27].

테라와다 불교에서는 초기불교의 순차적인 실천을 설명한 차제설법과 업설에 근거한 윤회설에 기반하여, 유익한 업[善業]인 베풂[布施], 지계(持戒), 사무량심(四無量心) 등의 천상에 이르는 선정(禪定) 수행에 의해 현재 삶에서의 행복 뿐만 아니라, 다음 생에서 누릴 수 있는 천상의 행복도 가르치고 있다.

본고에서는 『청정도론』을 위시로 하여 업과 윤회의 문제에 대해서 살펴본다. 『청정도론』17장, 통찰지의 토양에서 연기(緣起) 해설에 업과 윤회를 상세하게 설명하고 있기에, 12 연기와 24 조건을 토대로 하여 테라와다 불교의 업과 윤회설을 살펴보고자 한다.

\subsubsection{1 윤회의 근거인 무명과 존재의 갈애[有愛]}

『상윳따 니까야』에는 무명, 갈애, 그리고 윤회의 관계에 대해서 이렇게 말한다.

수행승들이여, 윤회는 그 시작을 알 수 없다. 최초 시간은 알려지지 않는다. 무명에 의해 뒤덮여 있고, 갈애로 속박되어 있는 존재들은 [생사의 세계에서] 헤매며 윤회한다 [28].

이 경전에서 볼 수 있듯이 윤회의 근거는 무명과 갈애인데, 청정도론의 저자 붓다고사는 『앙굿따라 니까야』의 두 경전을 인용하면서 무명을 출발점으로 하는 윤회[29]와 존재의 갈애(bhava-tanhā)를 출발점으로 하는 윤회[30]를 설명한다[31]. 무명과 갈애를 원인으로 하여 윤회를 설명한 것은, 무명이 지옥 등의 악도(惡道)로 인도할 업의 강한 조건이 되며, 색계나 무색계의 존재의 갈애는 선처(善處)로 인도할 업의 특별한 조건이기 때문이라고 한다. 초기경전에는, 무명은 다섯 덮개[五蓋]를 자양분(조건)으로 하며[32], 존재의 갈애는 무명을 자양분으로 하기[33] 때문에, 이러한 번뇌 사이의 상호 조건 관계에 대해 알 수 있지만, 무명에 의해 악업을 짓게 되면 악도에 윤회하고, 무명에 덮여있다 할지라도, 행복한 존재에 대한 갈애가 있으면, 살생 등을 삼가는 선업을 짓고 선처(인간 또는 천상)에 다시 윤회한다는 것을 보여준다. 


\subsubsection{2 무명을 조건을 행이 있다(無明緣行)의 행}

‘무명(無明)을 조건으로 행위[行]가 있다'는 12연기의 행(行)[34]에는 '공덕행, 비공덕행, 흔들림 없는 행의 3 가지가 있다. 이 세 가지 행위는, 모든 존재 세계에서의 업을 의미한다. 삼매와 같은 유익한 업[善業]에 의해서는 색계(色界)까지 도달할 수 있으며, 흔들림 없는 형성(āneñjābhisanikhārā)에 의해서 무색계(無色界)에 도달한다[35]. 여기에 몸의 행[身行], 말의 행[ㅁ行], 마음의 행[意行]이 있어, 모두 6가지 행이 있는데, 이 6가지는 세간적인 유익함[善]과 해로움[不善]의 의도(cetanā)일 뿐이다[36].

12 연기의 행(行)을 의도(cetanā)로 해석하기에, 행은 업과 같다. 무명을 조건해서 6 가지 의도인 행이 일어나며, 공덕행에는 보시, 지계 등에서 생긴 8가지 욕계(欲界)의 유익한 의도와, 삼매 수행에서 생긴 색계(色界)의 5 가지 유익한 의도의 13 가지 의도가 있다. 이러한 공덕행인 13 가지 의도는 『아비담마타상가하』의 욕계 유익한 마음 8 가지와 색계 유익한 마음 5가지이다[37]. 공덕이 되지 않는 불선업 (不善業)은 살생, 도둑질 등에서 생긴 12 가지 해로운 의도이며, 이것은 욕계의 해로운 마음 12 가지이다[38]. 흔들림 없는 행위는 무색계 삼매 수행에서 생긴 무색계(無色界)의 4가지 유익한 의도 즉 무색계의 4 가지 유익한 마음[39]이다. 이렇게 해서 29가지 의도가 있다. 이와 같이 고집멸도(苦集滅道)의 사성제에 대한 무지(無知)[40]인 무명을 조건으로 생긴 행(行) 즉 업은 29가지가 되며, 이 업에 의해 삼계(三界)에서 윤회하게 된다. 무명이 사라지고, 지혜(vijjā)가 생기면, 삼계의 29가지 의도가 모두 사라져, 윤회에서 벗어난다.

\subsubsection{12업의 4분류}

『청정도론』에서는 4가지 업을 3 종류로 제시하는데, 분류의 기준은 과보를 초래하는 순서이다. 첫 번째, 4가지 업은 금생에 받는 업, 다음 생에 받는 업, 미래 생(3생 후)에 받는 업[41], 효력을 상실한 업[42]의 4가지 업이다[43]. 효력을 상실한 업이란, 과거의 업이 있지만, 그 업의 과보는 없었고, 그 업의 과보는 없을 것이며, 그 업의 과보는 없다는 방식으로 효력을 상실한 업이라는 의미이다. 금생이나 내생에 과보를 받는 업이 조건을 만나지 못해 익지 못한 업이라는 의미이다. 미래 생에 받는 과보를 받는 업은 윤회가 있는 한 언젠가 그 과보를 받게 되어있는 업이다. 또 다른 4가지 업은 무거운 업, 습관적인 업, 임종에 가까워져 지은 업, 이미 지은 과거의 업이다[44]. 유익한 업, 해로운 업, 무거운 업, 가벼운 업 중에서 부모를 죽이는 업 등이나, 고귀한 경지[색계와 무색계선의 증득]의 업이 무거운 업이며, 이 무거운 업이 먼저 다음 생의 과보를 초래한다. 다음으로 습관적 업과 습관적이지 않은 업,둘 중에는 습관적인 업이 과보를 초래한다. 임종에 가까워져 지은 업은 임종 시 지은 업으로 그 업에 따라 태어난다. 위의 3 가지 업이 아니고, 반복하여 지은 업이 이미 지은 업이다.

또 다른 4가지 업은 생산하는 업, 돕는 업, 방해하는 업, 파괴하는 업이다[45]. 생산하는 업은 유익한 것이든 해로운 것이든, 재생연결과 삶에서 물질과 정신의 과보를 생기게 한다. 돕는 업은 과보를 생산할 수 없어 다른 업에 의해 재생연결이 되고 과보로서 즐거움과 괴로움이 생기면 그것을 돕고 지속시킨다.

방해업은 다른 업에 의해 재생연결이 주어지고 과보가 생길 때, 즐거움과 괴로움이 생기면 그것을 방해하고 막는다. 파괴업은 유익하거나 해로운 업이며, 앞의 3 가지 종류의 업이 없을 때는 이 이미 지은 업이 재생연결을 일으킨다. 방해하는 업은 다른 업에 의해 재생연결이 되고 과보로서 즐거움과 괴로움이 생길 때, 이를 방해하고 막는다. 파괴하는 업은 유익한 업이나 해로운 업으로 힘이 약한 다른 업을 파괴하고, 약한 업이 과보를 
일으킬 기회를 빼앗고, 자기의 과보를 내는 기회를 만드는 업이다.

위에서 말하는 열 두 가지 업과 그 업들의 과보는 업과 과보에 대한 붓다의 지혜에 의해서만 있는 그대로의 특징에 따라 명료하게 나타나기 때문에, 이 지혜는 수제자라 할지라도 그 어떤 제자들에게도 없는 붓다의 고유한 지혜이다.

\subsection{2『아비담마타상가하』의 업과 윤회}

테라와다 불교 아비담마의 핵심적인 강요서로 11 세기 아누룻다에 의해 저술된 『아비담마타상가하』는 5 세기에 저술된 『청정도론』 이후, 아비담마 교설 전체의 요점에 대한 이해를 위해서 가장 중요한 논서이다. 이 논서는 전체 9장으로 구성되어 있는데, 업과 윤회에 대해서는 5장 <인식과정을 벗어난 마음>에서 해설되었다. 5장은 4세계, 4재생연결, 4업, 4죽음을 내용으로 하며, 윤회하는 세간과 윤회에서 벗어난 출세간, 재생연결, 업과 그 과보 그리고 죽음을 다루고 있다.

\subsubsection{4가지 세계와 4가지 재생연결}

4세계[46]는 윤회세계인 욕계의 악처, 욕계의 선처, 색계, 무색계이다. 욕계의 악처는 지옥, 축생, 아귀, 아수라의 세계이다. 욕계의 선처는 인간과 욕계에 속하는 사천왕천, 도리천(삼십삼천), 야마천, 도솔천, 화락천, 타화자재천이다. 이렇게 욕계에는 모두 11 가지 세계가 있다. 색계는 초선에서 제사선이 이르는 색계선을 닦아 태어나는 곳인데 16 가지가 있다. 무색계는 무색계정(無色界定)을 닦아 태어나는 4가지이다. 이러한 4가지 세계는 31 가지 장소로 나뉜다. 4가지 재생연결은 이 4 가지 세계에 대한 재생연결이다. 4 가지 세상과 31 가지 장소에 대한 도표는 다음과 같다.

[표 1] 윤회의 세계[47]

[Table 1] The World of the Transmigration

(Great World-period: G.W; Deva year: D.Y; Incalculable kalpa; I.W; Not determined; N.D)

\begin{tabular}{|c|c|c|c|c|c|c|}
\hline \multicolumn{2}{|c|}{ Realm } & \multicolumn{4}{|r|}{ Plane } & Life span \\
\hline \multirow{4}{*}{$\begin{array}{l}\text { Realm of } \\
\text { Formlessn } \\
\quad \text { ess }\end{array}$} & \multirow{4}{*}{4} & & 31 & \multicolumn{2}{|c|}{ Realm of neither perception nor non-perception } & $\begin{array}{c}84000 \\
\text { G.W }\end{array}$ \\
\hline & & & 30 & \multicolumn{2}{|r|}{ Realm of nothingness } & $\begin{array}{c}60000 \\
\text { G.W }\end{array}$ \\
\hline & & & 29 & \multicolumn{2}{|r|}{ Realm of infinite consciousness } & $\begin{array}{c}40000 \\
\text { G.W }\end{array}$ \\
\hline & & & 28 & \multicolumn{2}{|r|}{ Realm of infinite space } & $\begin{array}{c}20000 \\
\text { G.W }\end{array}$ \\
\hline \multirow{7}{*}{$\begin{array}{l}\text { Realm of } \\
\text { Form }\end{array}$} & \multirow{7}{*}{16} & \multirow{7}{*}{$\begin{array}{c}\text { Fourth } \\
\text { Jhana }\end{array}$} & 27 & \multirow{5}{*}{ heavens of purity } & Realm of peerless devas & $\begin{array}{c}16000 \\
\text { G.W }\end{array}$ \\
\hline & & & 26 & & Realm of clear-sighted devas & 8000 G.W \\
\hline & & & 25 & & Realm of beautiful devas & 4000 G.W \\
\hline & & & 24 & & Realm of serene devas & 2000 G.W \\
\hline & & & 23 & & Realm of durable devas & 1000 G.W \\
\hline & & & 22 & & Realm of mindless devas & 500 G.W \\
\hline & & & 21 & & Realm of very fruitful devas & 500 G.W \\
\hline
\end{tabular}




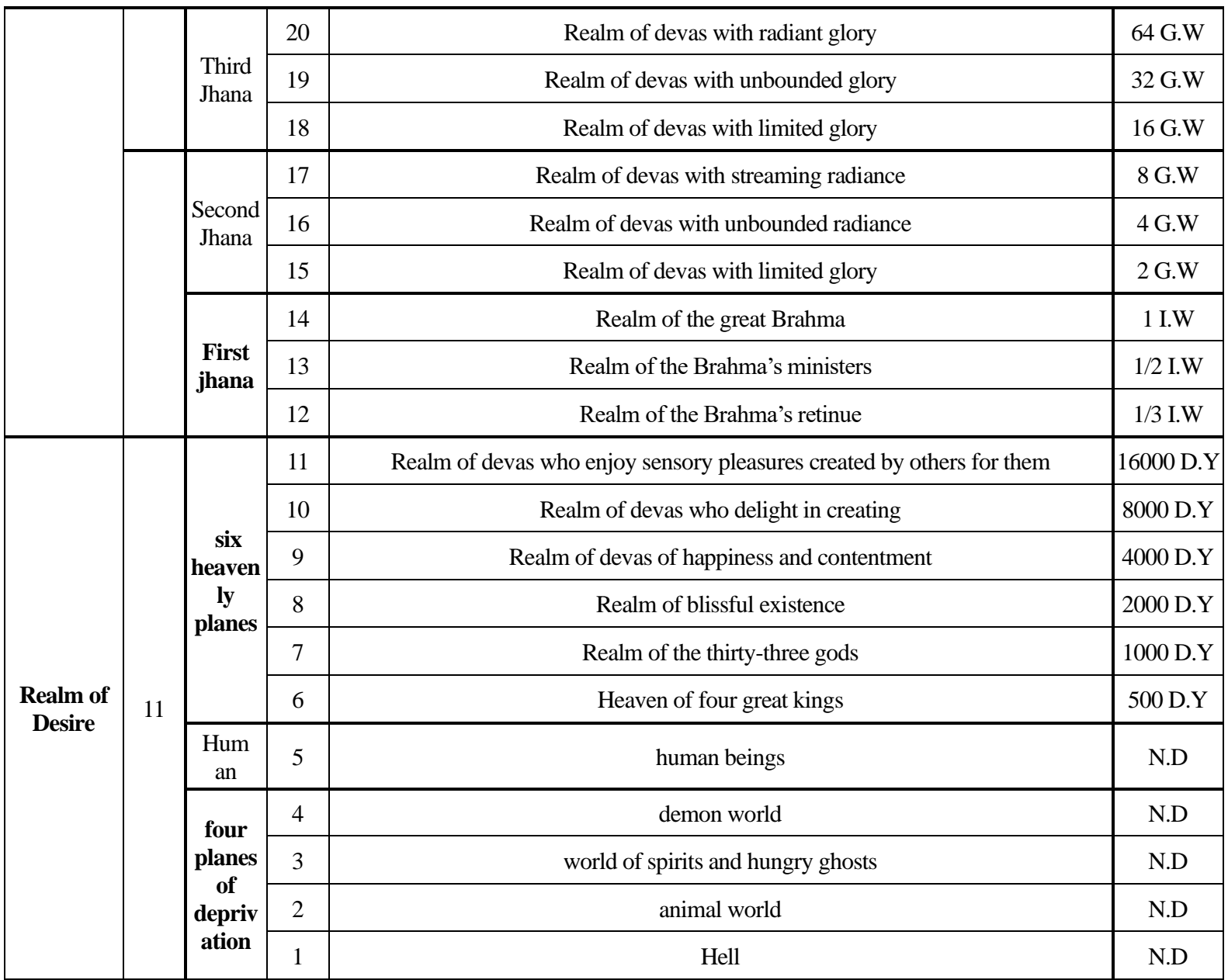

\subsubsection{4가지 업}

4 가지 업을 도표로 보면 다음과 같다.

[표 2] 4가지 업

[Table 2] Four Kamma

\begin{tabular}{|c|c|c|c|c|c|c|c|}
\hline \multicolumn{2}{|c|}{ Function } & \multicolumn{2}{|c|}{ Making order of kamma result } & \multicolumn{2}{|c|}{ Sequence of maturity } & \multicolumn{2}{c|}{ Making place of kamma result } \\
\hline 1 & Produce-kamma & 1 & Heavy kamma & 1 & $\begin{array}{c}\text { Kamma received in this } \\
\text { lifetime }\end{array}$ & 1 & \multicolumn{2}{c|}{ Bad kamma } \\
\hline 2 & Help-kamma & 2 & Kamma acted in death & 2 & $\begin{array}{c}\text { Kamma received in the } \\
\text { next lifetime }\end{array}$ & 2 & $\begin{array}{c}\text { Good kamma in the realm } \\
\text { of desire }\end{array}$ \\
\hline 3 & Obstacle-kamma & 3 & Habit-kamma & 3 & $\begin{array}{c}\text { Constantly receiving } \\
\text { kamma }\end{array}$ & 3 & $\begin{array}{c}\text { Good kamma in the realm } \\
\text { of form }\end{array}$ \\
\hline 4 & Destruction-kamma & 4 & $\begin{array}{c}\text { Kamma that has already } \\
\text { been built }\end{array}$ & 4 & Ineffective kamma & 4 & $\begin{array}{c}\text { Good kamma in the } \\
\text { Realm of formlessness }\end{array}$ \\
\hline
\end{tabular}

\subsubsection{3 업의 과보와 죽음 및 재생연결}

업은 그에 상응하는 과보를 낳는다. 이는 정해진 업의 법칙이다. 해로운 불 선업과 유 익한 선업은 그 업에 따른 과보를 고통스런 곳[惡處]와 행복한 곳[善處]에서의 재생연결 
의 마음을 생산한다.

존재의 죽음에는 4 가지 조건이 관여한다. 1.수명이 다함, 2.생산업이 다함, 3. 수명과 생 산 업 둘 다 다함, 4.파괴업이 끼어듦이라는 조건이다. 마지막 파괴업이 끼어들 때를 불시 의 죽음이라 하며, 나머지는 정상적 죽음이다.

누구나 임종 시, 바로 다음 생에서 직면할 재생연결식을 생산하는 업, 이전에 지은 업 의 모습[표상], 다음 생에 윤회할 곳의 모습[표상]이라는 3가지 중 하나가 임종하는 존재 의 의식에 나타난다[48]. 죽음 다음에 임종 시 나타난 3 가지 가운데 한 가지 모습을 대상 으로 하여 욕계나 색계나 무색계 중의 하나의 세계에서 재생연결식이 생긴다. 재생연결 후에는 죽음의 마음이 일어나기 전까지 존재의 마음은 계속해서 일어나고 사라진다. 일 상의 마음과 존재지속심(有分心, bhavanga-citta)의 형태로 마음은 한 순간도 끊어지지 않고 이어진다.

\section{3 현재 테라와다 불교의 업과 윤회에 대한 이해}

붓다는 재가 제자에게 보시, 지계, 천상(天上)의 실천법을 순서대로 가르쳤고, 현생과 다음생의 행복을 위해 이러한 실천을 하라고 했다. 그리고 붓다의 깨달음에 대한 믿음이 생겨, 사성제(四聖諦)를 듣고나서 수행할 때가 되면, 재가자에게도 사성제를 설명하여, 열 반을 체득하게 하였다. 붓다 당시, 재가자들 가운데 상당수가 예류(預流), 일래(一來), 불 환(不還)을 깨달았다[49]. 열반을 지향하는 사성제의 가르침은 재가자에게도 항상 공개되 어 있었다.

하지만 현재 테라와다 불교 국가를 방문하면, 법문이나 경전에 있는 담마와 실제 일상 종교 생활의 세계가 대조적이기 때문에 충격적이다. 특히 공덕행을 통해 공덕을 쌓는 것 은 개인의 현세에서의 복을 얻기 위한 일이므로, 공덕행을 통해 유익한 업을 나누는 것 이 발달했다[50]. 공덕행을 통해 공덕을 쌓는 일은 대부분의 테라와다 국가(스리랑카, 미 얀마, 태국, 라오스, 캄보디아 등)에서 널리 실천되고 있다. 주목할 점은 민속 차원에서 업설은 지속적으로 힘을 발휘한다는 점이다. Ames는 업과 윤회는 테라와다 불교 교리에 서 지엽적이 아니며, 전체적인 종교 체계로서 테라와다 불교는 교리적, 문화적으로 혁명 상태에 들어서 있다고 진단한다[51].

인류학적인 연구를 토대로 Winston King[52]과 Melford Spiro[53]는 더 좋은 재생을 목표 하는 '업의 불교(karmic Buddhism)'와 재생에서 벗어나는 '열반의 불교(nibbanic Buddhism)' 에 대해서 분명히 구분하는데, 이러한 입장에 대해서 Aronson은 비판적이다[54]. 이 비판 적 시각을 따라, 현대 테라와다 불교의 업의 불교와 열반의 불교의 관계는 다음과 같다.

$\operatorname{King}[55]$ 에 의하면, 업의 기법은 자애, 연민, 함께 기뻐함[사무량심 중 3가지] 등의 윤리 적 실천의 계발을 포함한다. 업의 기법은 옳음과 그름의 전쟁에서 투쟁하는 것이며, 행복 한 다음 생을 위한 것이다. 사무량심의 마지막 덕목인 평정은 선악의 세계에서 떠나는 열반의 기법이다.

Spiro[56]는 보시를 하는 것은 바람직한 다음 생을 얻기 위해 가장 많이 선택하는 기법이 라고 주장하며, 사무량심을 포함하는 명상은 열반의 불교라고 한다.

King은 교학에 뛰어난 승려들에게 의견을 구하고 번역된 경전을 통해 확인하는 과정을 통해서, 열반의 불교와 업의 불교 사이의 대극은 열반을 추구하는 출가자의 진정한 길과 더 낳은 내생을 구하는 재가자의 길 사이의 본래적인 구분을 의미하기 때문에 진실하다 는 입장을 주장하였다[57]. 
한편 Spiro는 경전의 교리와 일반 대중의 불교를 대비하였다. 따라서 경전의 교리는 열 반의 불교이고 일반 대중의 불교는 업의 불교라고 선택하였다[58]. 하지만, Spiro의 열반의 불교는 업과 관련 있으며, 유익한 업의 실천은 열반에 이르는 요인이 된다는 점을 간과 하였다. 따라서 Spiro의 업의 불교와 열반의 불교라는 용어의 선택에는 운이 없다 (unfortunate)고 Bruce는 비판적으로 말한다.

King과 Spiro는 사무량심에 대해 언급했지만, 둘 다 사무량심의 특징과 인생의 질뿐만 아 니라 열반과의 관계를 표현하지 못했다고 Aronson은 말한다. 그는 사무량심은 행복한 다 음 생을 위해서 두 바라문에게 제시되었음을 『디가 니까야』의「삼명경(三明經)」을 예시 하여 설명하면서, 이 사무량심은 항상 열반을 향해 있음을 강조한다[59].

다시 말하면, 업 vs 열반의 이분법적 사고방식은 초기불교 및 테라와다 불교의 전통적 인 가르침에도 어긋나고, 실천 수행에서도 문제점이 있음을 비판하며 현대의 테라와다 불교의 선업의 실천에 희한천상에 태어난다는 사상과 수행을 통한 열반 추구가 같은 목 적을 위한 수행이라는 점을 교학 전통과 수행전통을 통해서 확인할 수 있다.

여기에서 살펴보지 못한 타인을 위한 공덕 회향 사상과 조상을 대신한 보시 등의 선행 에 대한 초기불교 교설[60]과 연관이 있고, 공덕을 회향하는 사상도 초기불교 이래 불교 가 바라는 현생 및 내생의 행복을 물론 열반이라는 최상의 행복을 구하는 방법이다.

\section{3. 결론}

초기불교와 테라와다 불교의 업과 윤회에 대하여 초기불전과 테라와다의 주석문헌과 아비담마 논서를 중심으로 고찰해 보았다. 의도라고 정의된 업(karma, kamma)은 초기불교 의 기본 사상이자 고따마 붓다의 핵심 가르침이다. 욕계, 색계, 무색계의 삼계(三界)의 존 재들은 번뇌에 근거하여 업을 짓고 윤회하지만 영혼이나 자아라는 고정된 실체의 존재를 부정하는 무아 윤회를 초기불교는 주장한다. 청정도론 등의 주석문헌과 아비담마 문헌에 서는 업을 12 가지 4 분류로 더욱 치밀하게 분석하고 있으며 무아인 개별존재의 윤회에 대 한 기반으로 하였다.

초기불교 및 테라와다 불교에서는 물질 등을 베푸는 보시와 윤리적인 규범을 지키는 지계 등의 유익한 행위[善業]을 실행해서, 현재의 삶과 다음 생의 행복을 구하고자 하는 업의 길(karmic path)과 초기불교 수행론인 37보리분법을 실천하여 괴로움이 소멸한 열반 을 깨달아, 윤회에서 벗어나는 길(nibbanic path)이 서로 다른 두 길이 아니라, 같은 목적을 향한 길의 다른 단계임을 붓다가 제시한 것이라고 할 수 있다. 스리랑카, 태국, 미얀마 등의 테라와다 불교국가에서의 불교 신앙, 공덕행의 강조, 명상 실천은 현세와 다음 생의 행복을 구하되 궁극적으로는 완전한 행복이자 괴로움의 소멸인 열반을 향해가는 한 곳을 향해 나 있는 길이라 할 수 있다.

본고에서 자세히 다루지 못한 인도 힌두교와 자이나교의 업사상과 불교의 업사상과의

비교와 북방 아비달마 불교의 업사상과의 비교는 앞으로 연구과제로 남겨 놓는다.

\section{References}

[1] S. S. Jung, Rational Analysis on the Doctrine of Karma, Korea: Donggugsasang, (1979), Vol.12, pp.59-69.

[2] H. J. Yoon, Study of Non-self and Resurrection Problem, Korea Seoul: Minjogsa, (1991) 
[3] R. Morris \& E. Hardy, Anguttara-Nikāya(AN), UK Oxford: PTS, (1999), Vol.III, p.415.

[4] Dines Andersen and Helmer Smith, ed., Suttanipāta(Sn), UK Oxford: PTS, (1913), v.136, p.142.

[5] Dines Andersen and Helmer Smith, ed., Suttanipāta(Sn), UK Oxford: PTS, (1913), v.607, vv611-620.

[6] Dines Andersen and Helmer Smith, ed., Suttanipāta(Sn), UK Oxford: PTS, (1913), v.654.

[7] R. Morris \& E. Hardy, ed., Anguttara-Nikāya(AN), UK Oxford: PTS(1999), Vol.V, p.288.

[8] R. Morris \& E. Hardy, Aṅguttara-Nikāya(AN), UK Oxford: PTS, (1999), Vol.I, pp.134-135.

[9] V. Trenckner, C. Chalmers, Rhys Davids, Majjhima-Nikāya(MN), UK Oxford: PTS, (1925), Vol.III, pp.202-206.

[10] Nyanatiloka Mahathera, The Word of the Buddha, (Translation): J. S. Kim, Korea Seoul: Calm Voice Society, (2019), p.66.

[11] R. Morris \& E. Hardy, Aṅguttara-Nikāya(AN), UK Oxford: PTS, (1999), Vol.I, p.223.

[12] K. N. Jayatilleke, Early Buddhist Theory of Knowledge, UK London: George Allen \& Unwin, (1963), p.460.

[13] K. N. Jayatilleke, Early Buddhist Theory of Knowledge, UK London: George Allen \& Unwin, (1963), p.467.

[14] V. Trenckner, C. Chalmers, Rhys Davids, Majjhima-Nikāya(MN), UK Oxford: PTS, (1925), Vol.III, p.72.

[15] K. N. Jayatilleke, Early Buddhist Theory of Knowledge, UK London: George Allen \& Unwin, (1963), p.400.

[16] Bruce Matthews, Post-Classical Developments in the Concepts of Karma and Rebirth in Theravada Buddhism, Karma and Rebirth: Post-Classical Developments, USA: State University of New York Press, (1986), p.132.

[17] H. Oldenberg, Vinaya-pițaka(Vin), UK Oxford: PTS, (1879), Vol.I, 71. (Translation): B. S. Choi, Mahavagga 1, Korea Seoul: Sigongsa, (1998), pp.191-192.

[18] R. Morris \& E. Hardy, Añguttara-Nikāya(AN), UK Oxford: PTS, (1999), Vol.I, p.287.

[19] Rhys Davids, T. W. and Carpenter, J. E. Dīgha-nikāya, UK Oxford: PTS, (1889), Vol.I, p.115.

[20] R. Morris \& E. Hardy, Angguttara-Nikāya(AN), UK Oxford: PTS(1885-1910), Vol.I, p. 173-177.

[21] V. Trenckner, C. Chalmers, Rhys Davids, Majjhima-Nikāya(MN), UK Oxford: PTS, (1925), Vol.II, pp.214-228.

[22] Geumgang Center for Buddhist Studies, Understanding of Buddhism, Korea Seoul: Muwoosu, (2006), pp.49-50.

[23] Dines Andersen and Helmer Smith, Suttanipata: Group of Discourses, UK Oxford: PTS, (1913)

[24] C. A. F. Rhys Davids, Visuddhimagga, UK Oxford: PTS, (1975), p.603.

[25] C. A. F. Rhys Davids, Visuddhimagga, UK Oxford: PTS, (1975), p.544.

[26] F. L. Woodward, Commentary on the Samyutta-nikāya(SN-a), UK Oxford: PTS, (1929), Vol.I, p.329.

[27] Bhikkhu Bodhi, In the Buddha's Word: An Anthology of Discourses from the Pali Canon, USA: Wisdom Publications, (2005), p.2.

[28] L. Feer, Saṃyutta-nikāya(SN), UK Oxford: PTS, (1888), Vol.II, p.178.

[29] R. Morris \& E. Hardy, Anguttara-Nikāya(AN), UK Oxford: PTS, (1999), Vol.V, p.113.

[30] R. Morris \& E. Hardy, Angguttara-Nikāya(AN), UK Oxford: PTS, (1999), Vol.V, p.116.

[31] C. A. F. Rhys Davids, Visuddhimagga, UK Oxford: PTS, (1975), p.525.

[32] R. Morris \& E. Hardy, Anguttara-Nikāya(AN), UK Oxford: PTS, (1999), Vol.V, p.113.

[33] R. Morris \& E. Hardy, Anguttara-Nikāya(AN), UK Oxford: PTS, (1999), Vol.V, p.116.

[34] Johansson, The Dynamic Psychology of Early Buddhism, (Translation): W. S. Hur, Korea Seoul: Kyunghee 
University Publication, (2006), (Original Press, 1979, 1985), pp.68-91.

[35] Nyanatiloka, The Word of the Buddha, (Translation): J. S. Kim, Korea Seoul: Calm Voice Society, (2019), p.108.

[36] C. A. F. Rhys Davids, Visuddhimagga, UK Oxford: PTS, (1975), p.526.

[37] Ven Daerim, Ven Kakmug, translated by. Abhidhammatthasangaha, Vols. 1, Ulsan: Institution of Early Buddhist Texts, (2002), pp.136- 139, pp.149-155.

[38] Ven Daerim, Ven Kakmug, translated by. Abhidhammatthasangaha, Vols. 1, Ulsan: Institution of Early Buddhist Texts, (2002), pp.111-125.

[39] Ven Daerim, Ven Kakmug, translated by. Abhidhammatthasangaha, Vols. 1, Ulsan: Institution of Early Buddhist Texts, (2002), pp.159-162.

[40] C. A. F. Rhys Davids, Visuddhimagga, UK Oxford: PTS, (1975), p.531.

[41] R. Morris \& E. Hardy, Anguttara-Nikāya(AN), UK Oxford: PTS, (1999), Vol.I, pp.134-135.

[42] Ven Daerim, translated by, Visuddhimagga, Vols 1-3, Seoul: Institution of Early Buddhist Texts, (2004), Vol.3, pp.204-205, Foot note155.

[43] C. A. F. Rhys Davids, Visuddhimagga, UK Oxford: PTS, (1975), p.601.

[44] C. A. F. Rhys Davids, Visuddhimagga, UK Oxford: PTS, (1975), p.602.

[45] C. A. F. Rhys Davids, Visuddhimagga, UK Oxford: PTS, (1975), p.603.

[46] Ven Daerim, Ven Kakmug, translated by. Abhidhammatthasangaha, Vols. 1, Ulsan: Institution of Early Buddhist Texts, (2002), pp.412-439.

[47] https://cafe.daum.net/jetavana, May 25 (2015).

[48] T. Hayashi, On āsanna-kamma, Journal of Indian and Buddhist Studies, (2003), 52-1, pp.323-319. Pațis-a V. 576. 13-15.

[49] J. S. Kim, Enlightenment and Social Engagement of Early Buddhism, Korea Journal of Buddhist Studies, (2009), Vol.24, pp.57-105.

[50] Bruce Matthews, Post-Classical Developments in the Concepts of Karma and Rebirth in Theravada Buddhism, Karma and Rebirth: Post-Classical Developments, USA: State University of New York Press, (1986), p.135.

[51] Michael M. Ames, Magical-animism and Buddhism: A Structural Analysis of the Sinhalese Religious System, The Journal of Asian Studies, (1964), Vol.23, supplement S1: Aspects of Religion in South Asia, pp.21-52.

[52] Winston L. King, In the Hope of Nibbana: An Essay on Theravada Buddhist Ethics, USA: Open Court Publishing, (1964)

[53] Melford E. Spiro, Buddhism and Society - A Great Tradition and Its Burmese Vicissitudes, US: University of California Press, (1982)

[54] Harvey B. Aronson, The relationship of the karmic to the nirvanic in Theravada Buddhism, Journal of Religious Ethics, (1979), Vol.7, No.1, pp.28-36.

[55] Winston L. King, In the Hope of Nibbana: An Essay on Theravada Buddhist Ethics. USA: Open Court Publishing, (1964), pp.150-161, p.166.

[56] Melford E. Spiro, Buddhism and Society, New York: Harper Paperbacks,(1972), pp.47-48.

[57] Winston L. King, In the Hope of Nibbana: An Essay on Theravada Buddhist Ethics, USA: Open Court Publishing, (1964), p.169.

[58] Melford E. Spiro, Buddhism and Society - A Great Tradition and Its Burmese Vicissitudes, US: University of California Press, (1982), p.68. 
[59] Harvey B. Aronson, The relationship of the karmic to the nirvanic in Theravada Buddhism, Journal of Religious Ethics, (1979), Vol.7, No.1, p.30.

[60] R. Morris \& E. Hardy, Anguttara-Nikāya(AN), UK Oxford: PTS, (1999), Vol.V, pp.269-273. 